\title{
Prioritas Permasalahan Pengelolaan Keuangan Desa Pada Desa di Lubuk Pakam, Kabupaten Deli Serdang Sumatera Utara
}

\author{
Khrisna Fadillah Satyadira \\ Universitas Sumatera Utara, Indonesia
}

\section{Corresponding Author :}

ABSTRACT
Law Number 6 of 2014 mandates the Village Government to be in a position
to control its funds effectively. However, in practice, village monetary
management is still not effective. The reason of this find out about used to
be to analyze the precedence issues in village monetary management in
Lubuk Pakam, Deli Serdang Regency, North Sumatra Province. The
approach used is the Analytic Network Process (ANP). The effects of the
evaluation in this learn about point out that the electricity subculture is the
most dominant trouble variable in village economic administration in
Lubuk Pakam. In addition, based totally on the effects of the analysis, it can
additionally be viewed that the variables that have a larger have an impact
on are: energy sub-culture, financial sub-culture, periodic village
improvement plans, well-organized regulations, social sub-culture,
administration of BUMDes that is effective, as nicely as the existence of
partnerships with the commercial enterprise world (private).

Keywords

ANP, effectiveness, village finance, governance

\section{PENDAHULUAN}

Keseriusan Pemerintah untuk memajukan desa tentunya tidak hanya mengandalkan ketersediaan regulasi. Namun excellent will Pemerintah ini butuh bantuan dari seluruh stakeholders, agar tujuan pemerintah memperbaiki dan memajukan desa dapat segera terwujud melalui subsidi dana desa. Untuk mendukung suksesnya pengelolaan keuangan desa, kita butuh para kepala desa dan perangkat desa yang punya kapasitas. Mereka harus paham dan mengerti betul apa isi regulasi tentang desa. Jika tidak, pasti pengelolaan keuangan desa akan mengalami masalah serius ke depannya. Ada beberapa masalah dalam kaitan dengan pengelolaan keuangan desa selama ini. Pertama, keterbatasan regulasi. Bahwa true will dan political will pemerintah dengan menghadirkan regulasi khusus tentang desa sampai saat ini tidak cukup membantu kepala desa dan perangkatnya.

Kondisi ini terlihat jelas dari adanya keterlambatan dan kesulitan pemerintah desa dalam penyusunan perencanaan kegiatan dan keuangan desa. Hampir semua perundang-undangan desa yang memerintahkan adanya turunan peraturan 
Journal Economy And Currency Study (JECS)

Volume 3, Issue 1, January 2021

Page 34-45

melalui Perda dan Perbup sama sekali belum ditindaklanjuti. Contoh konkret adalah tidak adanya Perbup tentang perencanaan desa sebagai perintah pasal 89 Permendagri Nomor 114 Tahun 2014 tentang Pedoman Pembangunan Desa, perbup tentang daftar kewenangan berdasarkan hak asal-usul dan kewenangan lokal berskala desa sebagai perintah pasal 18 Permendesa Nomor 1 Tahun 2015, perbup tentang teknis penggunaan dana desa (APBN) tahun 2016 sebagai perintah pasal sebelas Permendesa Nomor 21 Tahun 2015 tentang Prioritas Penggunaan Dana Desa Tahun Anggaran 2016.

Peraturan lain yang mesti disediakan oleh Bupati melalui SKPD terkait, misalnya Perbup tentang pengadaan barang dan jasa di desa, serta perbup tentang pengelolaan keuangan desa. Padahal, turunan regulasi-regulasi ini sangat penting untuk membantu kepala desa dan perangkatnya. Semua regulasi yang ada saat ini sifatnya masih abstrak. Yang diatur adalah hal-hal bersifat umum. Kedua, ketiadaan anggaran. Tidak ada anggaran untuk membiayai penyusunan Design dan RAB. Selain itu, insentif untuk Tim Pelaksana Teknis Pengelolaan Keuangan Desa (PTPKD) juga tidak ada, termasuk TPK Desa.

Berdasarkan Undang-Undang (UU) Nomor 6 Tahun 2014 tentang Desa, disebutkan bahwa desa dan desa adat atau yang disebut dengan nama lain, adalah kesatuan masyarakat hukum yang memiliki batas wilayah yang berwenang untuk mengatur dan mengurus urusan pemerintahan, kepentingan masyarakat setempat berdasarkan prakarsa masyarakat, hak asal usul, danatau hak tradisional yang diakui dan dihormati dalam sistem pemerintahan Negara Kesatuan Republik Indonesia. Beberapa peraturan pelaksanaan atas UU Nomor 6 Tahun 2014 telah diterbitkan, baik berupa peraturan pemerintah (PP), Peraturan Menteri, Peraturan Bupati walikota. Beberapa peraturan yang diterbitkan oleh Kementerian Dalam Negeri adalah Peraturan Menteri Dalam Negeri (Permendagri) Nomor 111 Tahun 2014 tentang Pedoman Teknis Peraturan di Desa, Permendagri Nomor 112 Tahun 2014 tentang Pemilihan Kepala Desa, Permendagri Nomor 113 Tahun 2014 yang telah diganti dengan Permendagri Nomor 20 Tahun 2018 tentang Pengelolaan Keuangan Desa, Permendagri Nomor 114 Tahun 2014 tentang Pedoman Pembangunan Desa, Permendagri Nomor delapan puluh tiga Tahun 2015 tentang Pengangkatan dan Pemberhentian Perangkat Desa, Permendagri Nomor delapan puluh empat Tahun 2015 tentang Susunan Organisasi dan Tata Kerja Pemerintah Desa, Permedagri Nomor 1 Tahun 2016 tentang Pengelolaan Aset Desa, Permendagri Nomor 14 Tahun 2016 tentang Perubahan Kedua Atas Peraturan Menteri Dalam Negeri Nomor 32 Tahun 2011 tentang Pedoman Pemberian Hibah dan Bantuan Sosial Yang Bersumber Dari Anggaran Pendapatan dan Belanja Daerah.

Bantuan keuangan dari APBD Provinsi dan APBD Kabupaten kota diberikan berdasarkan kemampuan keuangan pemerintah daerah. Sumber pendapatan lain 
Journal Economy And Currency Study (JECS)

Volume 3, Issue 1, January 2021

Page 34-45

yang dapat diusahakan oleh desa berasal dari Badan Usaha Milik Desa (BUMDesa), pengelolaan pasar desa, pengelolaan kawasan wisata skala desa, pengelolaan tambang mineral bukan logam dan tambang batuan dengan tidak menggunakan alat berat, serta sumber lainnya dan tidak untuk diperjualbelikan. Penggunaan seluruh pendapatan desa, termasuk dana desa dan ADD, harus dipertanggungjawabkan oleh pemerintahan desa secara akuntabel. Namun dalam prakteknya, masih banyak ditemukan permasalahan-permasalahan terkait pengelolaan dana desa, antara lain: dalam tataran input, proses dan output terdapat permasalahan pengalokasian dana desa per desa tidak sesuai dengan formulasi sesuai ketentuan, penyaluran dana desa dari Rekening Kas Umum Daerah (RKUD) ke Rekening Kas Desa (RKD) terlambat, terdapat Pemerintah Kabupaten kota yang menetapkan syarat tambahan atas penyaluran dana desa, penggunaan dana desa dan ADD yang tidak sesuai peruntukan, realisasi dana desa tidak dapat dipertanggungjawabkan, korupsi dana desa oleh Kepala DesaPerangkat Desa, penunjukkan pendamping desa oleh Pemerintah Provinsi tidak sesuai ketentuan, perangkat desa tidak melakukan fungsinya untuk melakukan bimbingan ke desadesa, realisasi dana desa tidak melibatkan masyarakat setempat, dan seterusnya.

Permasalahan-permasalahan tersebut mengindikasikan pemerintahan desa, yang sejak awal merupakan community self governance (Aziz 2016), sebenarnya belum cukup siap untuk menjalankan tugas dan fungsi layaknya sistem pemerintahan otonomi daerah yang ada di kabupaten. Banyaknya pengaturan yang diterbitkan oleh pemerintah pusat maupun pemerintah daerah juga mengancam sifat sosial komunitas desa yang seharusnya memiliki kebebasan dalam menentukan dan memenuhi kebutuhannya. Outcome dari pengelolaan keuangan desa, sejak dimulainya penyaluran dana desa langsung ke desa untuk melakukan pembangunan, yaitu meningkatkan kesejahteraan masyarakat desa juga belum terlihat secara nyata. Berdasarkan uraian-uraian tersebut, maka rumusan masalah pada penelitian ini adalah bagaimana prioritas permasalahan pada pengelolaan keuangan desa di Lubuk Pakam kabupaten deli serdang Provinsi Sumatera Utara.

\section{METODE PENELITIAN}

Metode yang digunakan pada penelitian ini adalah menggunakan Analytic Network Process (ANP). ANP merupakan salah satu metode dalam pengambilan keputusan berdasarkan banyak kriteria (Multiple Criteria Decision Making - MCDM) yang dikembangkan oleh Thomas L Saaty (2015: 85). Metode ini merupakan pendekatan baru pada metode kualitatif yang merupakan perkembangan dari metode Analytic Hierarchy Process (AHP). Kelebihan ANP adalah metode pengambilan keputusan yang prosesnya sederhana sehingga dapat digunakan dalam masalah yang kompleks. 
Journal Economy And Currency Study (JECS)

Volume 3, Issue 1, January 2021

Page 34-45

\section{HASIL DAN PEMBAHASAN}

Dari hasil pengolahan statistics hasil kuesioner terhadap klaster sub kultur governance yang meliputi sub kultur kekuasaan, sub kultur ekonomi, dan sub kultur sosial diperoleh hasil seperti yang terlihat pada Gambar 1.

Gambar 1 : Pengaruh Klaster Sub Kultur Governance

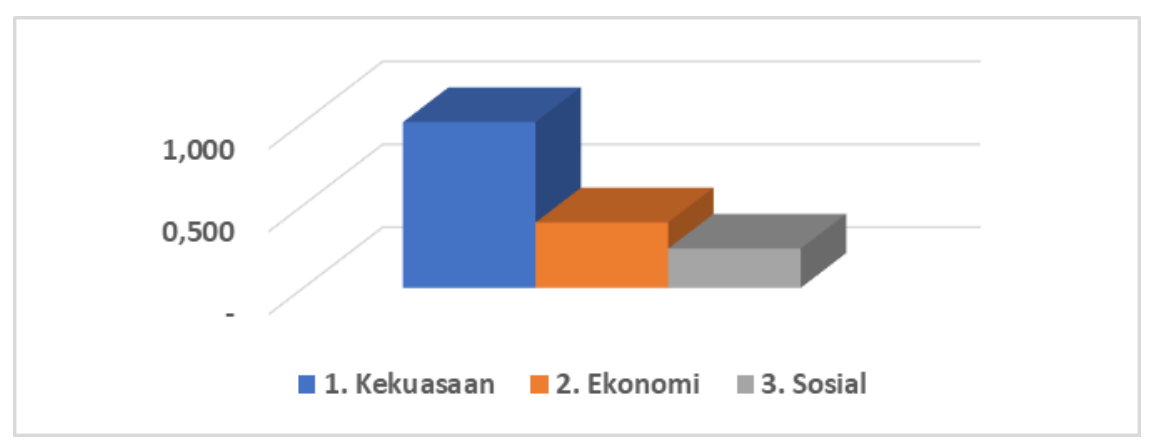

Berdasarkan grafik tersebut, dapat dilihat bahwa para pakar yang menjadi responden pada penelitian ini meyakini bahwa pada tataran sub kulturgovernance, faktor kekuasaan menjadi faktor yang saat ini dianggap paling berpengaruh terhadap efektifitas pengelolaan keuangan desa, diikuti oleh faktor ekonomi dan faktor sosial. Hal tersebut mengindikasikan bahwa Pemerintah sebagai regulator harus memperhatikan dan menjadikan Faktor Kekuasaan sebagai prioritas utama dalam upaya meningkatkan efektivitas pengelolaan Keuangan Desa. Selanjutnya hasil analisa ANP - pada klaster kekuasaan seperti disajikan dalam Gambar four di bawah ini terlihat bahwa pada sub klaster Kekuasaan, adanya rencana pembangunan desa secara periodik dianggap menjadi faktor yang paling berpengaruh, diikuti oleh adanya regulasi yang tertata dengan baik dan tata kelola keuangan yang efektif.

Gambar 2 : Pengaruh Klaster Kekuasaan

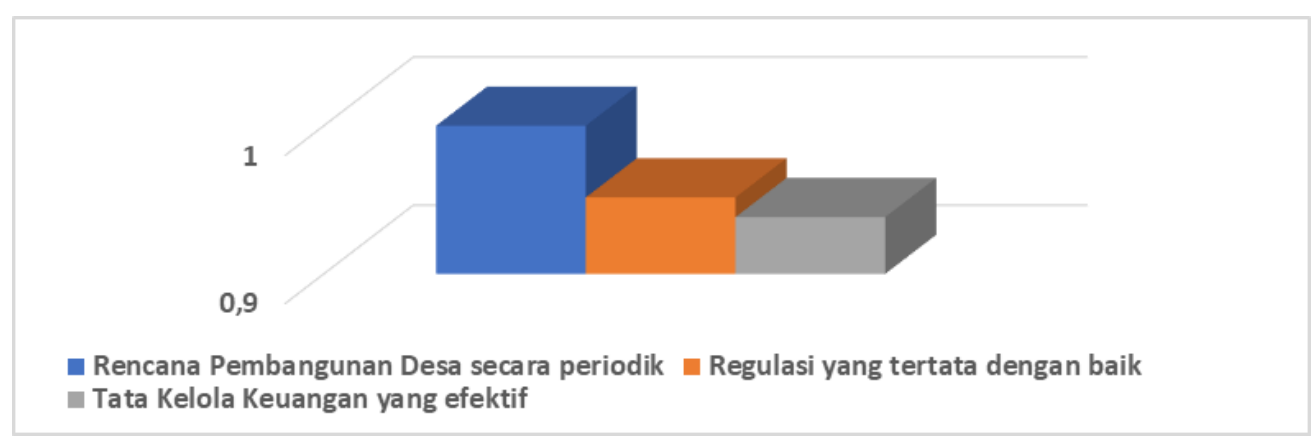

Sedangkan pada subklaster Rencana Pembangunan Desa, hasil pengolahan ANP disajikan dalam Gambar 5 berikut : 


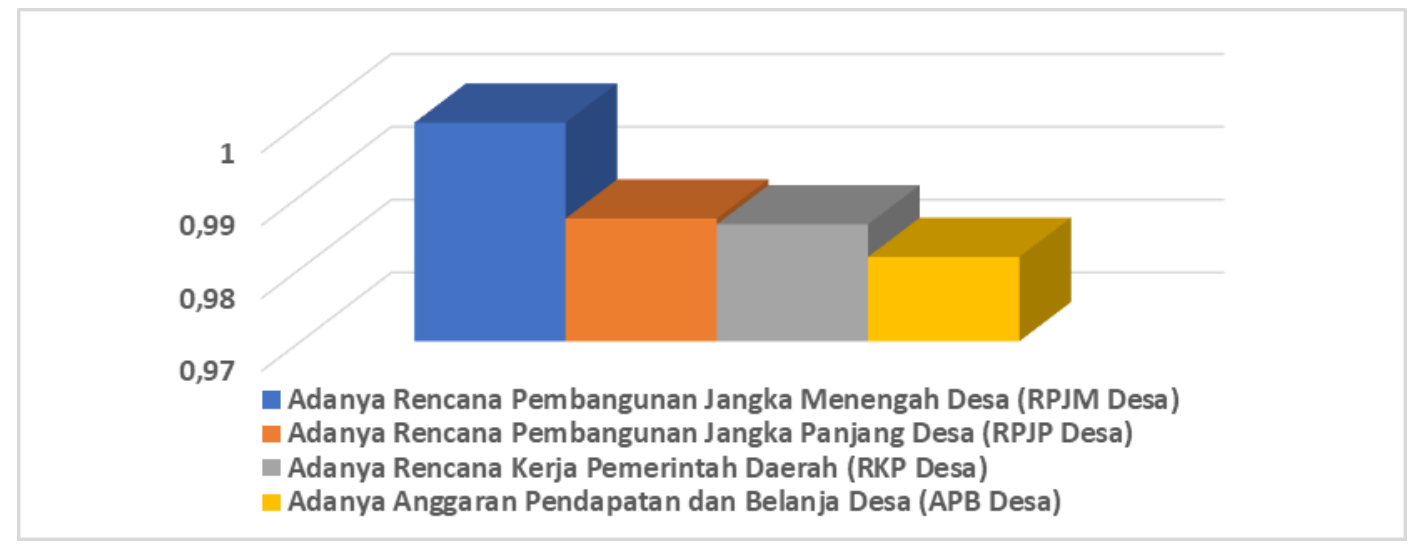

Dalam Grafik diatas terlihat bahwa Adanya Rencana Pembangunan Jangka Menengah Desa (RPJM Desa) dianggap sebagai faktor yang paling berpengaruh dan harus dijadikan sebagai prioritas utama yang harus dibenahi oleh Pemerintah. Jika melihat nilai bobot prioritas dari setiap faktor yang ada pada sub klaster Perencanaan Pembangunan Desa, bobot terkecil adalah Adanya Anggaran Pendapatan dan Belanja Desa sebesar 0,97, selisih antar faktor tersebut sangat kecil. Artinya, para pakar yang menjadi responden pada penelitian ini sepakat bahwa semua faktor pada sub klaster Perencanaan Pembangunan Desa menjadi prioritas yang harus dibenahi.

Selain aspek perencanaan desa, dalam subkultur kekuasaan diungkapkan juga pentingnya sub klaster regulasi yang tertata dengan baik. Hal ini menunjukkan bahwa masyarakat desa di lubuk pakam memerlukan peraturan terkait dengan pengelolaan keuangan desa yang jelas, lengkap, tidak tumang tindih, tidak bertentangan dengan peraturan lainnya, serta praktis dan mudah dipahami serta dilaksanakan. Dalam sub klaster regulasi yang tertata dengan baik ini hasil ANP yang diperoleh disajikan dalam Gambar 6 berikut.

\section{Gambar 6 Pengaruh Penataan Regulasi}

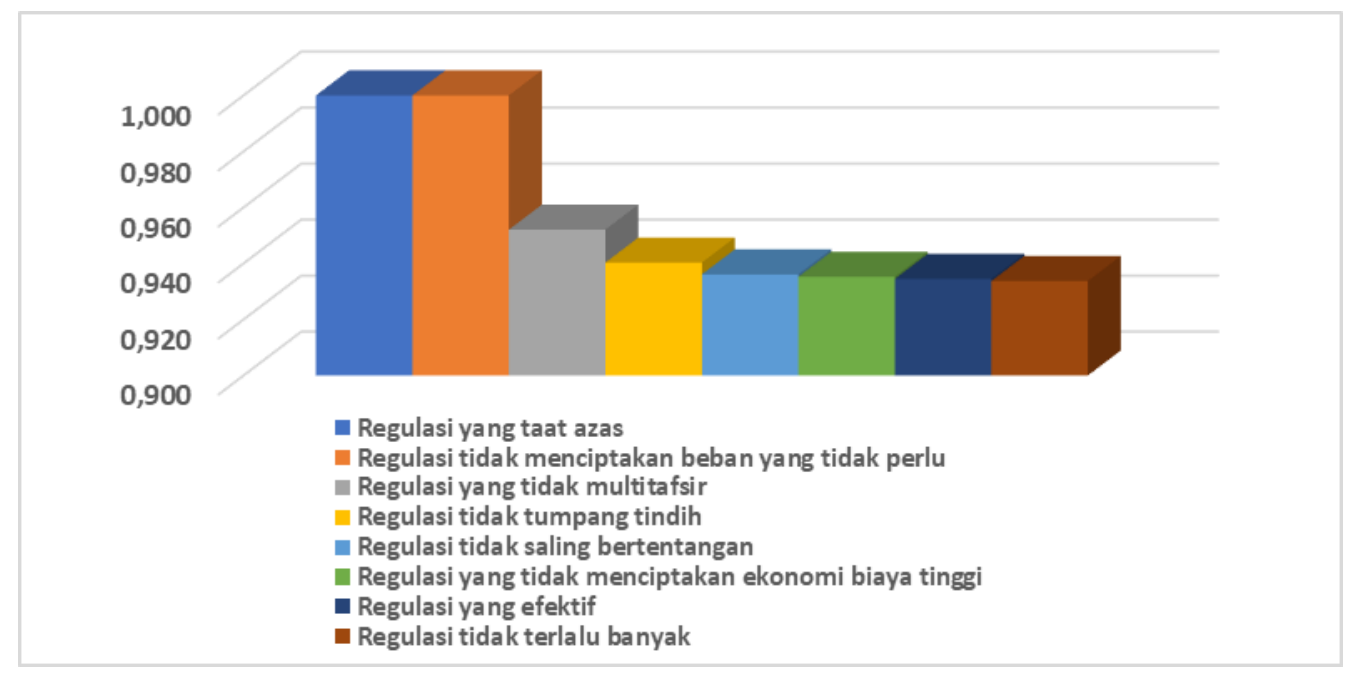




\section{Journal Economy And Currency Study (JECS) \\ Volume 3, Issue 1, January 2021}

Dari persepsi para pakar yang menjadi responden dalam penelitian ini diperoleh informasi bahwa regulasi yang taat azas dan regulasi yang tidak menciptakan beban yang tidak perlu merupakan dua faktor yang paling mempengaruhi penataan regulasi yang baik. Artinya regulasi yang seharusnya ada hendaknya taat azas (sesuai dengan kaidah-kaidah regulasi) dan tidak menimbulkan beban yang tidak perlu. Sub Kultur Kekuasaan juga mengidentifikasi faktor tata kelola keuangan yang baik sebagai salah satu faktor yang mempengaruhi upaya meningkatkan kesejahteraan masyarakat desa di Lubuk Pakam. Berdasarkan hasil analisis diketahui bahwa faktor pembinaan dan pengawasan yang rekomendasinya dapat ditindaklanjuti, yang memberikan informasi untuk perbaikan, perencanaan keuangan desa yang sinkron dengan RKP, pelaporan keuangan desa yang transparan, dan pengawasan dan pembinaan yang dilakukan oleh orang yang kompeten merupakan faktor-faktor yang memberikan pengaruh terbesar dalam sub klaster tata kelola keuangan desa yang baik.

Variabel-variabel tersebut menunjukkan bahwa tata kelola keuangan desa masih banyak tergantung pada pihak-pihak yang berada di luar struktur pemerintahan desa yang memiliki tugas dan kewenangan untuk melakukan pembinaan dan pengawasan terhadap pengelolaan keuangan desa. Peran tersebut dimiliki oleh Pemerintah Pusat, Pemerintah Provinsi Sumatera Utara, Pemerintah Kabupaten Deli Serdang termasuk Pendamping Desa. Selanjutnya dalam sub kultur ekonomi diidentifikasi faktor pengelolaan BUMDesa yang efektif dan kemitraan dengan dunia usaha sebagai dua faktor penting yang berpengaruh terhadap sub kultur ekonomi dalam meningkatkan kesejahteraan masyarakat .

Gambar 7 : Pengaruh Klaster Ekonomi

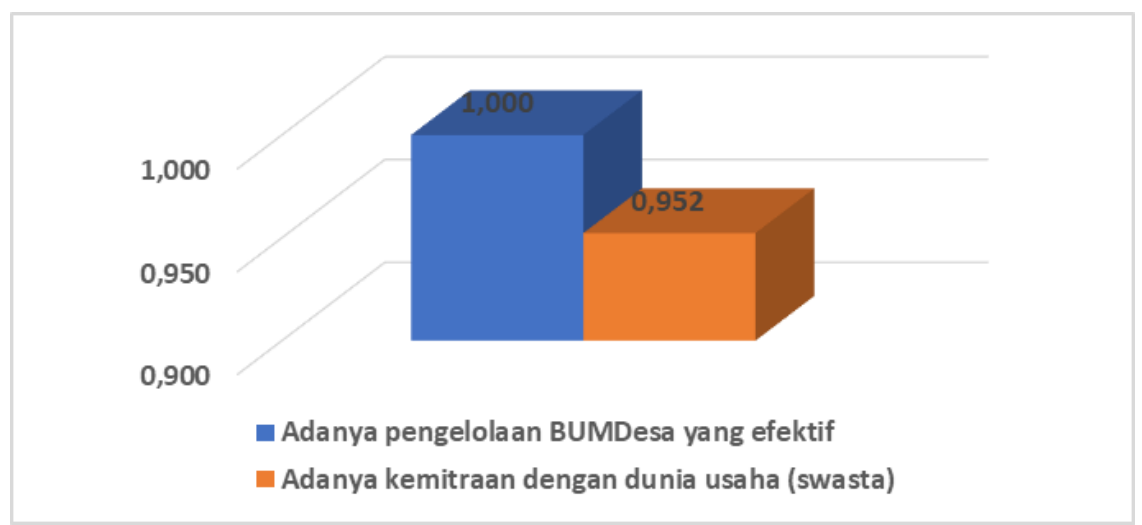


Dari garifk tersebut terlihat bahwa Adanya pengelolaan BUMDesa yang efektif merupakan faktor yang paling berpengaruh dalam sub klaster ekonomi untuk meningkatkan kesejahteraan masyarakat. Namun jika dilihat perbedaan dengan faktor Adanya kemitraaan dengan dunia usaha (swasta), yaitu sebesar 0,05 maka dapat dikatakan bahwa kedua faktor tersebut memiliki dampak yang hampir sama untuk meningkatkan kesejahteraan masyarakat desa di Lubuk Pakam. Untuk mewujudkan BUMDesa yang efektif terdapat variabel yang paling menentukan pengelolaan BUMDesa yaitu pemodalan finansial, yang saat ini didapatkan dari penyertaan modal dari keuangan desa, disamping sumber daya manusia yang belum kompeten.

Selain itu dapat diketahui juga bahwa faktor adanya modal finansial dalam pengelolaan BUMDesa merupakan faktor terpenting, yang menunjukkan bahwa untuk menjalankan BUMDesa secara efektif modal finansial merupakan faktor yang paling diperlukan. Namun tingkat kepentingan faktor ini juga hampir sama besarnya dengan faktor-faktor seperti: Adanya prinsip partisipatif dalam pengelolaan BUMDesa, Adanya modal manusia dalam pengelololaan BUMDesa, serta Adanya prinsip akuntabel dalam pengelolaan BUMDesa. Faktor-faktor tersebut yang diyakini para pakar dalam kuesioner ANP dalam penelitian ini yang paling berpengaruh terhadap efektivitas pengelolaan BUMDesa. Sementara itu, dalam sub klaster kemitraan dengan pihak swasta hasil pendapat para pakar disajikan dalam Gambar Delapan Dengan hasil yang tidak berbeda jauh, prinsip-prinsip yang ditawarkan dalam kemitraan dengan dunis usaha seperti prinsip saling menguntungkan, prinsip saling membesarkan dan prinsip saling membutuhkan merupakan prinsip-prinsip yang penting dalam membina kemitraan antara desa dengan dunia usaha dalam rangka meningkatkan kesejahteraan masyarakat desa.

Gambar 8 : Pengaruh Kemitraan Dengan Dunia Usaha.

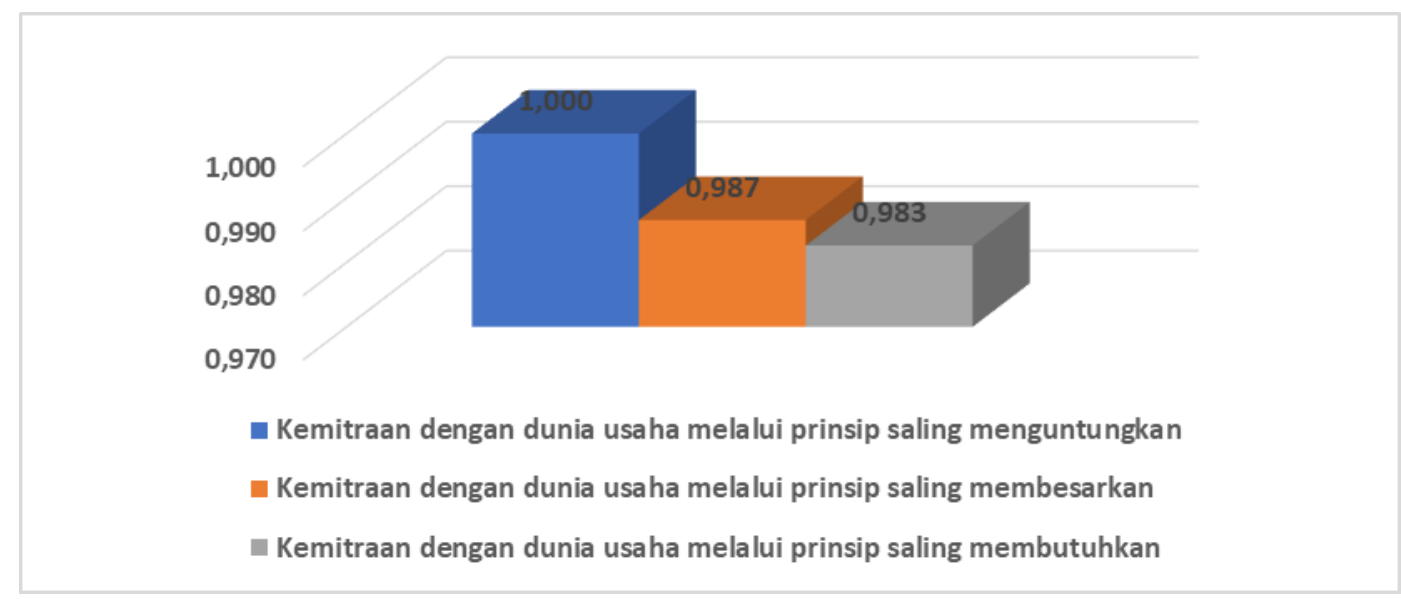


Dalam sub kultur sosial diperoleh informasi bahwa faktor Adanya upaya kemandirian masyarakat dan Adanya Pengembangan Kemampuan Masyarakat diyakini oleh para responden dalam penelitian ini sebagai faktor yang paling mempengaruhi efektivitas pengelolaan keuangan desa dalam meningkatkan kesejahteraan masyarakat. Hasil pengolahan ANP atas sub kultur sosial ini disajikan pada gambar 9 berikut :

Gambar 9: Pengaruh Klaster Sosial

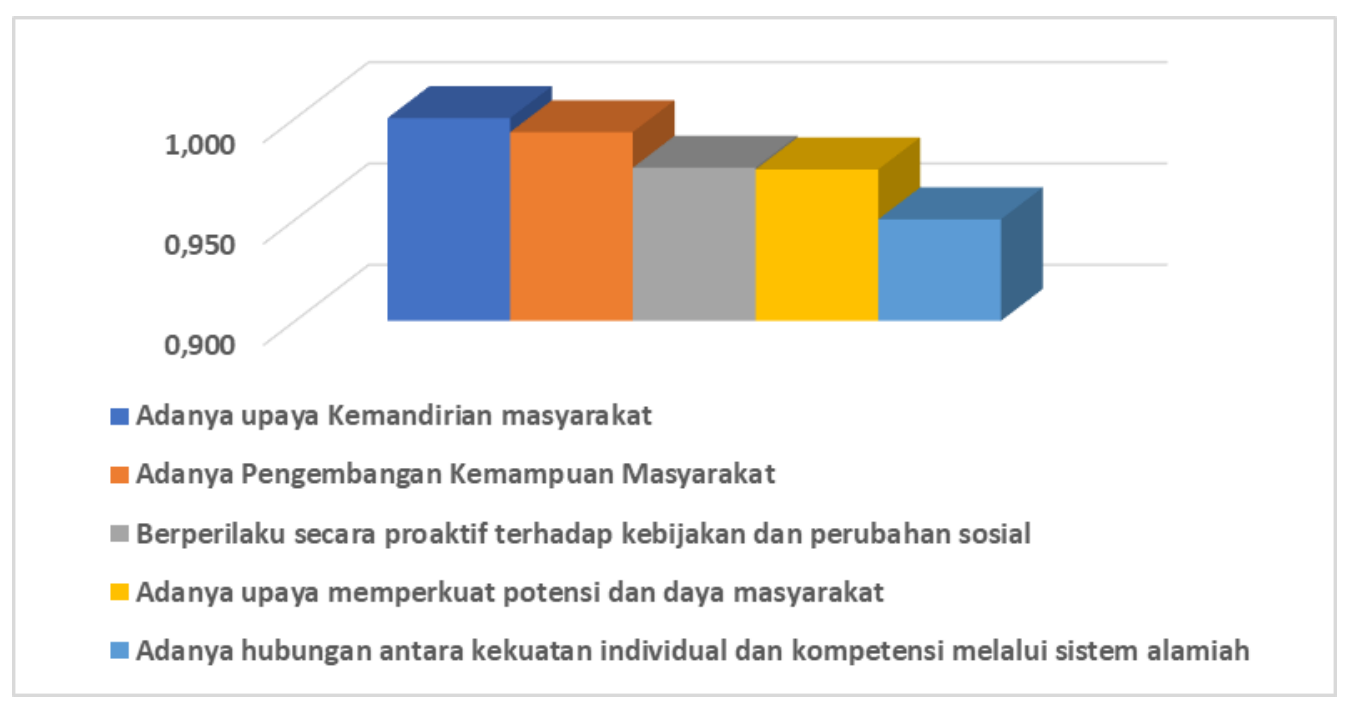

Berdasarkan hasil-hasil tersebut terlihat bahwa variabel-variabel yang memiliki pengaruh lebih besar adalah: sub kultur kekuasaaan, sub kultur ekonomi, adanya rencana pembangunan desa secara periodik, adanya regulasi yang tertata dengan baik, sub kultur sosial, adanya pengelolaan BUMDesa yang efektif, adanya kemitraan dengan dunia usaha (swasta). Dengan demikian, dapat disimpulkan bahwa variabel-variabel tersebut merupakan permasalahan yang dianggap paling memiliki tingkat prioritas yang tinggi. Terkait sub kultur kekuasaan, dapat dijelaskan bahwa masyarakat desa di lubuk pakam secara umum masih merupakan masyarakat tradisional, yang mengandalkan intervensi dari sub kultur kekuasaan (Pemerintah Kabupaten Deli Serdang atau Pemerintah Desa). Semakin baik sub kultur kekuasaan ini akan semakin penting dampaknya bagi peningkatan kesejahteraan masyarakat desa.

Terkait dengan sub kultur ekonomi (sektor privat) dapat dijelaskan bahwa variabel ini menunjukkan bahwa peningkatan kesejahteraan masyarakat dapat lebih cepat dicapai bilamana sektor privat juga berpartisipasi. Peningkatan ekonomi ini dilakukan dengan pendekatan ekonomi kerakyatan, yaitu pengembangan dunia usaha berbasis partisipasi masyarakat. Selanjutnya, 
adanya perencanaan pembangunan desa secara periodik merupakan variabel penting yang menjelaskan bahwa untuk meningkatkan kesejahteraan masyarakat desanegeri diperlukan perencanaan pembangunan yang baik dan terjadwal secara periodik. Dengan demikian pengukuran peningkatan kesejahteraan masyarakat desa dapat dilakukan secara periodik juga. Adanya tata kelola keuangan yang efektif merupakan variabel penting berikutnya. Hal ini menjelaskan bahwa peningkatan kesejahteraan masyarakat desa di lubuk pakam dapat dicapai dengan intervensi pemerintahan setempat, partisipasi sektor swasta, perencanaan pembangunan desa secara periodik, regulasi yang tertata dengan baik, serta tata kelola keuangan yang efektif. Efektivitas tata kelola keuangan dijelaskan berdasarkan teori Gibson (2009: 36) yang meliputi kejelasan tujuan, strategi untuk mencapai tujuan, proses analisa dan perumusan kebijakan yang mantap, perencanaan yang matang, penyusunan application yang tepat, ketersediaan sarana dan prasarana yang diperlukan, serta sistem pengawasan dan pengendalian yang bersifat mendidik.

\section{KESIMPULAN}

Analisis permasalahan pada pengelolaan keuangan desa di Lubuk pakam, kabupaten Deli serdang Provinsi Sumatera Utara pada penelitian ini berdasarkan tiga subkultur yaitu subkultur kekuasaan, subkultur ekonomi, dan subkultur sosial. Berdasarkan hasil analisis diketahui bahwa subkultur kekuasaan menjadi variabel permasalahan yang paling dominan dibandingkan subkultur yang lainnya. Hal ini mengindikasikan bahwa masyarakat desa di Lubuk pakam secara umum masih merupakan masyarakat tradisional, yang mengandalkan intervensi dari sub kultur kekuasaan (Pemerintah kabupaten Deli Serdang atau Pemerintah Desa). Semakin baik sub kultur kekuasaan ini akan semakin penting dampaknya bagi peningkatan kesejahteraan masyarakat desanegeri. Selain itu, berdasarkan hasil analisis juga dapat diketahui bahwa variabel-variabel yang memiliki pengaruh lebih besar adalah: sub kultur kekuasaaan, sub kultur ekonomi, adanya rencana pembangunan desa secara periodik, adanya regulasi yang tertata dengan baik, sub kultur sosial, adanya pengelolaan BUMDesa yang efektif, serta adanya kemitraan dengan dunia usaha (swasta). Pengelolaan keuangan desa bagi saya sebenarnya tidak ada masalah. Jika semua regulasi yang belum mengatur secara jelas dibuat sedetail mungkin melalui berbagai peraturan turunan, seperti peraturan bupati, SK maupun juklak/juknis. Sepanjang kita bisa menyiapkan perangkat peraturan ini dengan baik, maka seluruh jenis pengelolaan keuangan desa pasti tepat sasaran. 
Selain ketersediaan peraturan di atas, hal lain yang mesti disiapkan oleh pemerintah desa adalah dokumen RPJMDes, RKPDes dan APBDes. Ketiga jenis dokumen penting ini harus dilegalisasi dengan peraturan desa. Tanpa peraturan desa, ketiga dokumen tersebut tidak akan bisa digunakan dan bermakna bagi kepentingan masyarakat. Untuk itu, sinergisitas pemerintah desa dan BPD serta tim penyusun hendaknya selalu terbangun dengan baik dalam menyediakan dokumen perencanaan desa. Tidak boleh ada konflik antar kelembagaan di desa. Penguatan kapasitas untuk tim PTPKD dan TPK Desa harus lebih sering dilakukan. Wujudnya bisa melalui IST, OJT dan bimtek. Selain itu, bisa juga dilakukan reposisi personalia pengelola keuangan desa. Untuk memperkuat kapasitas pengelola keuangan desa, tentunya kita juga perlu memperhatikan aspek pendanaannya.

Harus jelas sumber anggaran untuk insentif bagi para tim pengelola keuangan desa. Satu hal yang mesti kita ketahui bersama, bahwa pemerintahan desa tidak bisa paham dan menjadi mampu dengan sendirinya. Tanpa ada intervensi positif dan pendampingan, sampai kapapun pemerintah desa tidak akan tahu. Kita tidak boleh melakukan pembiaran terhadap pemerintah desa. Di sinilah pemerintah daerah dan pendamping profesional harus hadir. Artinya, para pimpinan SKPD sebagai pembantu bupati wajib menyediakan segala perangkat aturan yang dapat membantu pemerintah desa, mendesain anggaran, serta memberi telaahan yang konstruktif. Jadi tidak mesti semua menunggu perintah bupati. Jika semua menuggu, pasti jelas terlambat. Sudah saatnya, para pimpinan SKPD harus lebih inovatif dan terlibat secara utuh dalam segala jenis pengelolaan keuangan desa. Sejalan dengan besarnya harapan publik terhadap pengelolaan keuangan desa. Pemerintah daerah juga mestinya mulai melibatkan partisipasi masyarakat dalam seluruh pengelolaan keuangan desa atau membangun Community Based Monitoring (CBM).

\section{PENGAKUAN/ PENGHARGAAN}

Peneliti mengucapkan terima kasih yang besar terhadap semua pihak terkait yang telah membantu dan mendukung terlaksananya penelitian ini baik secara formal, non formal, materil maupun non materil, terutama Dinas PMD Kabupaten Deli Serdang, Bapak Camat Lubuk Pakam, dan Kasi Pemdes Kecamatan Lubuk Pakam yang telah memberikan informasi terkait desa di kecamatan Lubuk Pakam, dan Kepala Desa se kecamatan Lubuk Pakam Kabupaten Deli Serdang yang telah bersedia memberikan informasi dan data yang diperlukan untuk melengkapi penelitian ini. 


\section{REFERENCES}

Adisasmita, Rahardjo, 2011, Manajemen Pemerintahan Daerah, Yogyakarta: Graha Ilmu .

Ascarya, 2012. Konsep Dasar ANP: Pendekatan Baru dalam Penelitian Kualitatif. Pusat Pendidikan dan Studi Kebank- sentralan. Bank Indonesia. Jakarta.

Ascarya dan Yumanita D., 2011. Determinan dan persistensi margin perbankan konvensional dan syariah di Indonesia, Working Paper Series No. WP1004. Aziz, N. L. L., 2016). The Village Autonomy And The Effectiveness Of Village Fund. Jurnal Penelitian Politik, 13(2), 193-211.

Barney, Jay, 1991. "Firm Resources and Sustained Competitive Advantage", Journal of Management, 1991, Vol. 17, No. 1, 99-120.

DAPP-BAPENAS, 2012. Laporan Akhir Koordinasi Strategis Reformasi Regulasi Tahun 2012 Direktorat Analisa Peraturan Perundang-undangan. Kementerian Perencanaan Pembangunan Nasional Badan Perencanaan Pembangunan Nasional.

De Massis, A., Kotlar, J., Frattini, F., Chrisman, J. J., \&amp; Nordqvist, M., 2016. Family governance at work: Organizing for new product improvement in household SMEs. Family Business Review, 29(2), 189-213.

Elvina dan Musdhalifah, 2019. Peningkatan Kesejahteraan Masyarakat melalui Partisipasi dan Implementasi Kebijakan dengan Efektivitas Pembangunan Program Dana Desa sebagai Variabel Intervening. JSHP Vol. three Nomor 12019.

Gibson, Ivancevich, Donnelly, 1996. Organisasi: Perilaku, Struktur, Proses, Edisi Kedelapan Jilid Satu, Terjemahan Nunuk Ardiani, Jakarta: Binarupa Aksara.

Mitchell, R.K., Agle, B.R., \&amp; Wood, D.J., 1997. Toward a Theory of Stakeholder Identification and Salience: Defining the Principle of who and What Really Counts.

Peraturan Menteri Dalam Negeri (Permendagri) Nomor 111 Tahun 2014 tentang Pedoman Teknis Peraturan di Desa.

Peraturan Menteri Dalam Negeri Nomor 112 Tahun 2014 tentang Pemilihan Kepala Desa.

Peraturan Menteri Dalam Negeri Nomor 20 Tahun 2018 tentang Pengelolaan Keuangan Desa.

Peraturan Menteri Dalam Negeri Nomor 114 Tahun 2014 tentang Pedoman Pembangunan Desa .

Peraturan Menteri Dalam Negeri Nomor 83 Tahun 2015 tentang Pengangkatan dan Pemberhentian Perangkat Desa. 
Journal Economy And Currency Study (JECS)

Volume 3, Issue 1, January 2021

Page 34-45

Peraturan Menteri Dalam Negeri Nomor 84 Tahun 2015 tentang Susunan Organisasi dan Tata Kerja Pemerintah Desa.

Peraturan Menteri Dalam Negeri Nomor 1 Tahun 2016 tentang Pengelolaan Aset Desa.

Peraturan Menteri Dalam Negeri Nomor 14 Tahun 2016 tentang Perubahan Kedua Atas Peraturan Menteri Dalam Negeri Nomor 32 Tahun 2011 tentang Pedoman Pemberian Hibah dan Bantuan Sosial Yang Bersumber Dari Anggaran Pendapatan dan Belanja Daerah.

Ridlwan, Z., 2014. Urgensi Badan USAha Milik Desa (Bumdes) dalam Pembangun Perekonomian Desa. Jurnal Ilmu Hukum, 8(3), 424-440.

Saaty, Thomas L, 2008. Decision Making with the analytic community process, Int.J. Services Sciences, Vol I No. 1.

Undang-Undang Nomor 6 Tahun 2014 Tentang Desa.

Winarni, Tri, 1998. Memahami Pemberdayaan Masyarakat Desa Partisipatif dalam Orientasi Pembangunan Masyarakat Desa Menyongsong Abad 21: Menuju Pemberdayaan Pelayanan Masyarakat. Yogyakarta: Adita Media 